\title{
The Design of Samarinda Batik Motif Through Semiotics Approach and Cultural Study
}

\author{
Etwin Fibrianie Soeprapto*, Dwi Cahyadi, Ditha \\ Nizaora \\ Design Department \\ Politeknik Negeri Samarinda \\ Samarinda, Indonesia \\ *etwin.f@gmail.com,dwicahyadi@polnes.ac.id, \\ dthnizaora@gmail.com
}

\author{
Puji Astuti Amalia \\ Maritime Department \\ Politeknik Negeri Samarinda \\ Samarinda, Indonesia \\ pujiastutiamalia@polnes.ac.id
}

\begin{abstract}
Batik is an Indonesian cultural heritage that is already global and characterizes Indonesian society. In each batik motif has a meaning content. The meaning in a sign is also called semiotics. The plan to move the state capital of Indonesia to East Kalimantan has brought some changes, one of which is in the field of batik. The introduction of the East Kalimantan area, especially the Sungai Pinang district which has natural, tourism and religious resources, is also a solution to introduce the prospective capital city of the country. The purpose of making the batik motif development in Sungai Pinang District is as a solution to the problem of introducing the national capital area. With quantitative methods and semiotics analysis, a batik design was made in the Sungai Pinang sub-district. Based on questionnaire data obtained 5 designs of new batik motifs in Sungai Pinang sub-district which were obtained by exploring historical data of history, tourism, natural resources of the Sungai Pinang area in particular and East Kalimantan in general. The hope of developing this new batik is that it can be used as a medium for tourism promotion, to increase the income of Samarinda batik craftsmen during the Covid 19 pandemic.
\end{abstract}

Keywords-state capital of Indonesia, sub-district Sungai Pinang East Kalimantan, smiotics, batik development, tourism promotion

\section{INTRODUCTION}

Batik art is a local cultural heritage of Indonesia that has high artistic value and a value of local wisdom [1]. Batik has been a part of Indonesian culture for a long time. It is not only known and sought-after by the domestic community, but also foreign communities. Therefore, it is not surprising that Indonesian batik motifs are famous in foreign countries and become a fashion trend.

Motifs are the basic element in batik because, in every batik, motifs are the points of interest. Many things can be learned from batik motif design, such as the cultural background, beliefs, customs, the natural environment, the spiritual, etc. [2]. Although batik motifs have experienced cultural development and acculturation [3], batik motif did not shift the meaning and did not eliminate the characteristics of the batik itself which had traditional values and philosophical meanings [4-7]. Semantics is the study of meaning, or more precisely, the study of the relation between linguistic expressions and their meanings [8,9]. Different from the definition of semantics, in the study of semiotics, visual language can also be observed as a sign system, both single sign and set of signs [10]. The existence of Indonesian batik is greatly supported by the development of batik itself both in terms of the unique motifs, coloring, symbolic meaning contained, and the price of batik on the market. Motif batik design will be better if they have an attractive design, a meaning sign, and especially they can represent the taste of the customer.

Samarinda as the capital of East Borneo province has many districts, one of them is the Sungai Pinang district. Sungai Pinang district has many cultures, such as the history of the district, the natural resources, the human resources, the religion, the artwork, the tourism, etc. The design which is directed by emotional content can be considered as the heart of current design practices, research, and education [11]. This paper explores the perception of batik users using the semiotic semantic method, evaluating actual users' perception of the visual elements such as color, semiotic of motif batik as the object of the study. The obtained data used to identify the creative process of batik is hoping to gain applicable knowledge for the preservation as well as a new development of Sungai Pinang District batik design.

\section{LITERATURE REVIEW}

\section{A. Semiotics and Semantics}

Product design has a purpose or a meaning, both for designers or users. Successful products must be able to inform the designers and users' desires, also to evoke the users' attraction. Semiotics is the study of signs and semantics is the study of their meaning. The emotional content of the design product is more important for Ergonomics and Design Science 
[11]. Product semantics was developed and introduced by Krippendorff and Butter [12] and is defined as the study of symbolic qualities of man-made shapes, in the cognitive and social context of their use. Krippendorf's wrote, product semantics describes the relationship between user and designer, shown figure 1 [13]. Six factors in the semiotics of communication are the sender, receiver of code, message, communication channel, and reference, emphasize the theory of signs and their understanding in a certain context. Semiotics of significance emphasizes the understanding of a sign [14].

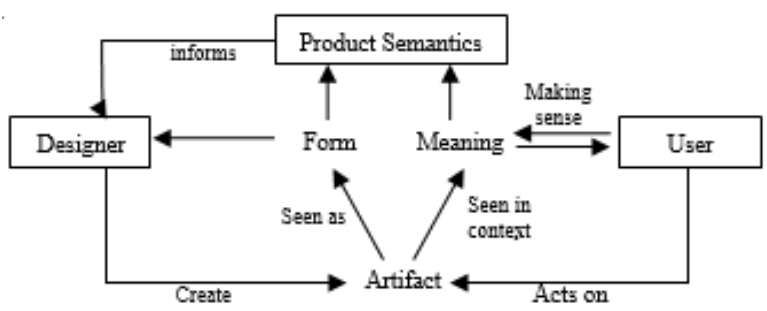

Fig. 1. Krippendorrf's proposed model of the relationship between users and designer [13].

There are two different reactions to the process of applying the semantic content of a new, the first reaction is based on knowledge and dependent on social and cultural background, and the second reaction is user emotional. The emotional response is an automatic response to our thoughts related to the situation or object that we have seen figure 2 [11].

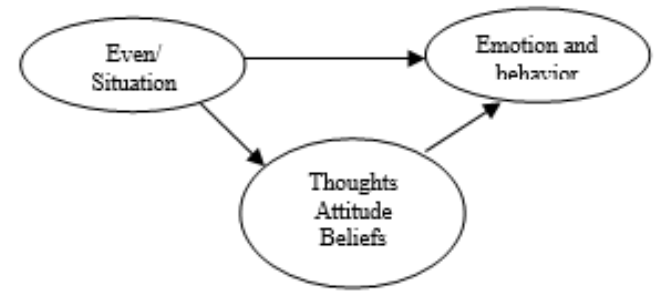

Fig. 2. Emotional respon flow [11].

\section{B. Relocation of the Capital and Cultural Value}

Every batik design implies a meaning. Batik is a hereditary culture. Traditional batik is batik whose motive is bound by certain rules that must be obeyed and with certain isen, for example Batik Kerokan, Batik Jumputan, Batik Becak and others. Meanwhile, modern batik is a development of traditional batik where modern batik has a motif that is not bound by certain rules and certain isen. Modern batik is free and independent. For example, abstract batik motifs, painting motifs, regional cultural motifs, inspired by regional natural resource motifs, tourism, or inspired by the social structure of the community in an area.

President Joko Widodo in 2019 decided that the capital city of Indonesia would move to East Kalimantan to be precise in parts of North Penajam Paser Regency and parts of Kutai Kartanegara Regency in East Kalimantan. This has had a major impact on various sectors, one of which is in the culture and tourism sectors. In the field of culture and tourism, one of which is the development of the capital's batik motif which will later become the characteristic of the capital city of Indonesia.

Currently there are many batik designs in the new capital with regional characteristics of East Kalimantan. Based on news of liputan6.com, the capital's batik will have characteristics adopted from East Kalimantan culture, such as the use of bold colors but still pleasing to the eye, a symbol of the tree of life, characterized by Kalimantan flora and fauna and the form of a statue. The planned relocation of the capital is also an opportunity to develop new batik designs. The new batik designs will add to the diversity of batik in Indonesia [15].

The visual images are according to the experts stated as the semiotic signs have been successfully brought the messages to the person who saw it and understandable enough to interpreted by the addressee [16-18]. Attractive batik has 2 main components, both line and color [19]. The perception of color is often influenced by emotional conditions and psychic someone [20]. Batik patterns are often inspired by natural conditions, the environment, philosophy, knowledge, customs, and local elements that are unique to each region [20]. Figure 3 shown "Pucuk Bunga Taman: and Figure 4 shown "Anggrek Hitam suku Dayak Modang” are examples of the many existing East Kalimantan motifs resulting from the exploitation of existing culture and natural resources [21].

The examples of batik motif that can be developed as new motifs Capital of Indonesia, shown in figure 5. The batik of East Kutai Regency has motifs of ferns, black orchids, clubs, roots, hornbills, mbui birds and seated banyan birds. This motif resembles the flora resources in the Kalimantan forest. Batik development can also be done based on regional characteristics. As shown in figure 6, Development of Batik with the theme of the oldest mosque in Samarinda, East Kalimantan. Blue color symbolizes peace in religion, the red color on the tendrils symbolizes courage, strength and energy, as well as a passion for action, and symbolizes joy. The tendril motifs symbolize the flora of the Kalimantan forest.

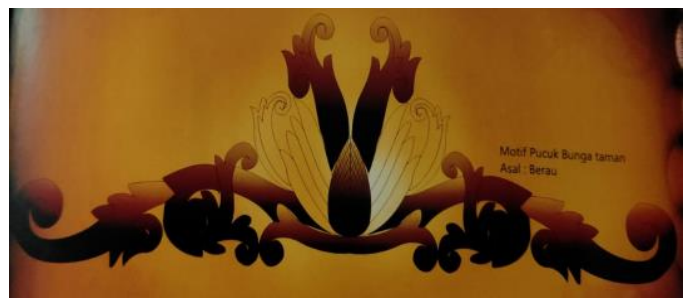

Fig. 3. Motif Kalimantan Timur "Pucuk Bunga Taman" [21]

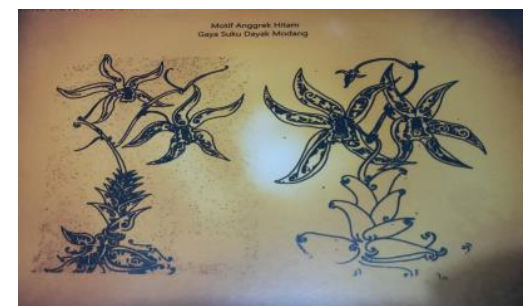

Fig. 4. Motif Kalimantan Timur “ Motif Anggrek Hitam suku Modang [21] 


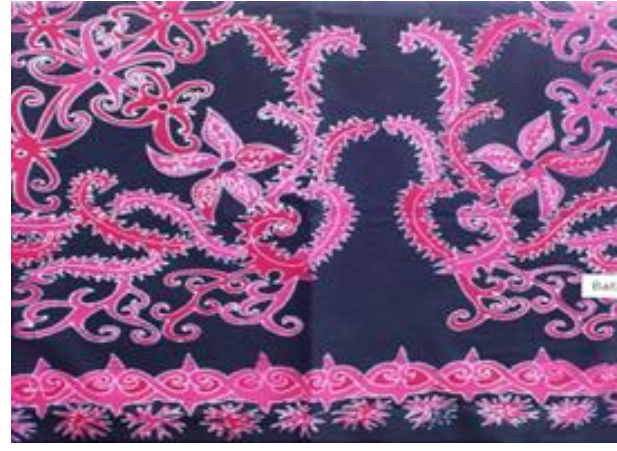

Fig. 5. Motif batik Kutai Timur [15].

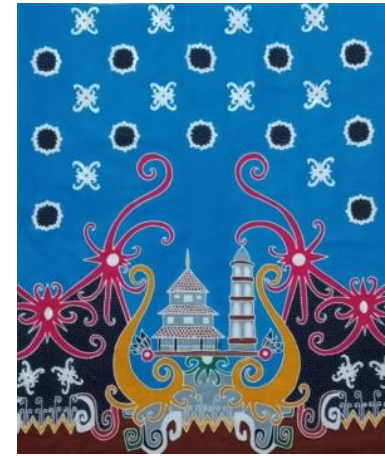

Fig. 6. Motif batik Masjid tertua di Samarinda, East Kalimantan.

\section{METHODS}

This study uses a qualitative method with an ethnographic approach with semantic categorization based on the semiotics of the object to be studied. This semantic categorization is influenced by narrative semantics, a semantic value of a product. Ethnography is a qualitative strategy in which the researcher studies an intact cultural group in a natural setting over a prolonged period of time by collecting primarily observational and interview data [22]

\section{A. Sample}

The sample in this study were people with an age range of $20-50$ years, 60 respondents. They were divided into 10 small research groups.

\section{B. State of Art}

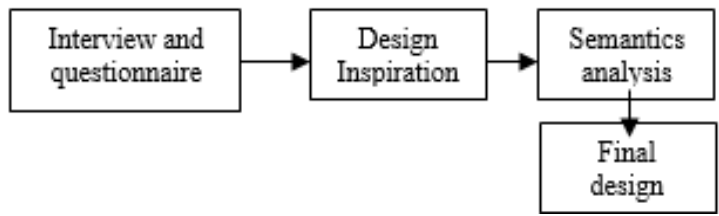

Fig. 7. State of art research.

1) Interview and quesionaire: The first step in the interview 1 is to collect words which are the attributes needed in designing a batik [16,23]. The second step is to interview users to find out their responses based on semantic categorization formulas. The results of the interview will be recorded as reference data in bringing up batik attributes [24]. Due to the Covid-19 pandemic period, which did not allow researchers to interact with many people, interviews were conducted online by giving essay questions to 50 users via google forms link. Then, Input data from users in steps 1 and 2 are grouped into design attribute groups.

2) Design inspiration: an important part of any product design activity is the inspiration process. A creative design comes from a combination of analytical, inspirational and creative thinking $[2,25,26]$. Source of inspiration is possible for designers to build associations of ideas by applying the principles of equality, contrast, and closeness as well supported by a source of inspiration [27], Based on this, the researcher focused the research on the Sungai Pinang district as the object of research. The highlights are about the history, culture, natural resources, tourism and symbols of the area. Sources of inspiration is collected through a deliberate information search effort carried out to meet the specifications.

\section{FINDING AND DISCUSSION OF RESULTS}

The research results reveal that there are several factors that contributed to Sungai Pinang batik design as shown in Table. 1. The contributing factors are grouped by semantic categories. They are described as follows:

TABLE I. INTERVIEW RESULT

\begin{tabular}{|l|l|l|}
\hline No & $\begin{array}{l}\text { Semantic } \\
\text { categories }\end{array}$ & \multicolumn{1}{c|}{ Interview Result } \\
\hline 1 & $\begin{array}{l}\text { Emotional } \\
\text { Semantics }\end{array}$ & $\begin{array}{l}\text { The Kaltim's Sulur motif, pucuk rebung are known } \\
\text { both nationally and internationally }\end{array}$ \\
\hline 2 & $\begin{array}{l}\text { Empirical } \\
\text { Semantics }\end{array}$ & $\begin{array}{l}\text { The colors that characterize East Kalimantan are } \\
\text { red, black, yellow and white, but does not rule out } \\
\text { all the attractive colors }\end{array}$ \\
\hline 3 & $\begin{array}{l}\text { Cognate } \\
\text { Semantic }\end{array}$ & $\begin{array}{l}\text { Curved lines and dotted line represent the flow of } \\
\text { river water }\end{array}$ \\
\hline 4 & $\begin{array}{l}\text { Contextual } \\
\text { Semantics }\end{array}$ & $\begin{array}{l}\text { The Pinang tree symbolizes the natural resources } \\
\text { that are found in Sungai Pinang sub-district }\end{array}$ \\
\hline 5 & $\begin{array}{l}\text { Functional } \\
\text { Semantics }\end{array}$ & $\begin{array}{l}\text { Batik is usually used formally and officially so it } \\
\text { must have an elegant design and color }\end{array}$ \\
\hline 6 & $\begin{array}{l}\text { Evaluative } \\
\text { Semantics }\end{array}$ & $\begin{array}{l}\text { Batik use cool materials; fabric is not stiff and } \\
\text { absorbs sweat }\end{array}$ \\
\hline 7 & $\begin{array}{l}\text { Cultural } \\
\text { Semantics }\end{array}$ & $\begin{array}{l}\text { The Sulur motifs characterize East Kalimantan, } \\
\text { Vihara Maitreya, the largest Buddhist Center in } \\
\text { Southeast Asia, as a symbol of spiritual tourism, } \\
\text { Pinang Tree and the river to be a symbol of regional } \\
\text { geography }\end{array}$ \\
\hline
\end{tabular}

\section{A. Final Design}

The visual elements of the Sungai Pinang batik motif were analyzed based on semiotics which includes three things:

1) Syntaxsis: Is an activity which studied the sign inside another sign system that is shows similarity or continuity.

2) Semantic: Studying the relationship between signs and their meanings or denotations and connotations of these signs. 
3) Pragmatics: Studying the relationship of the sign with the wearer.
The results of the analysis are described in table 2 below:

TABLE II. SEMIOTIC ANAL YSIS OF BATIK SUNGAi PINANG District

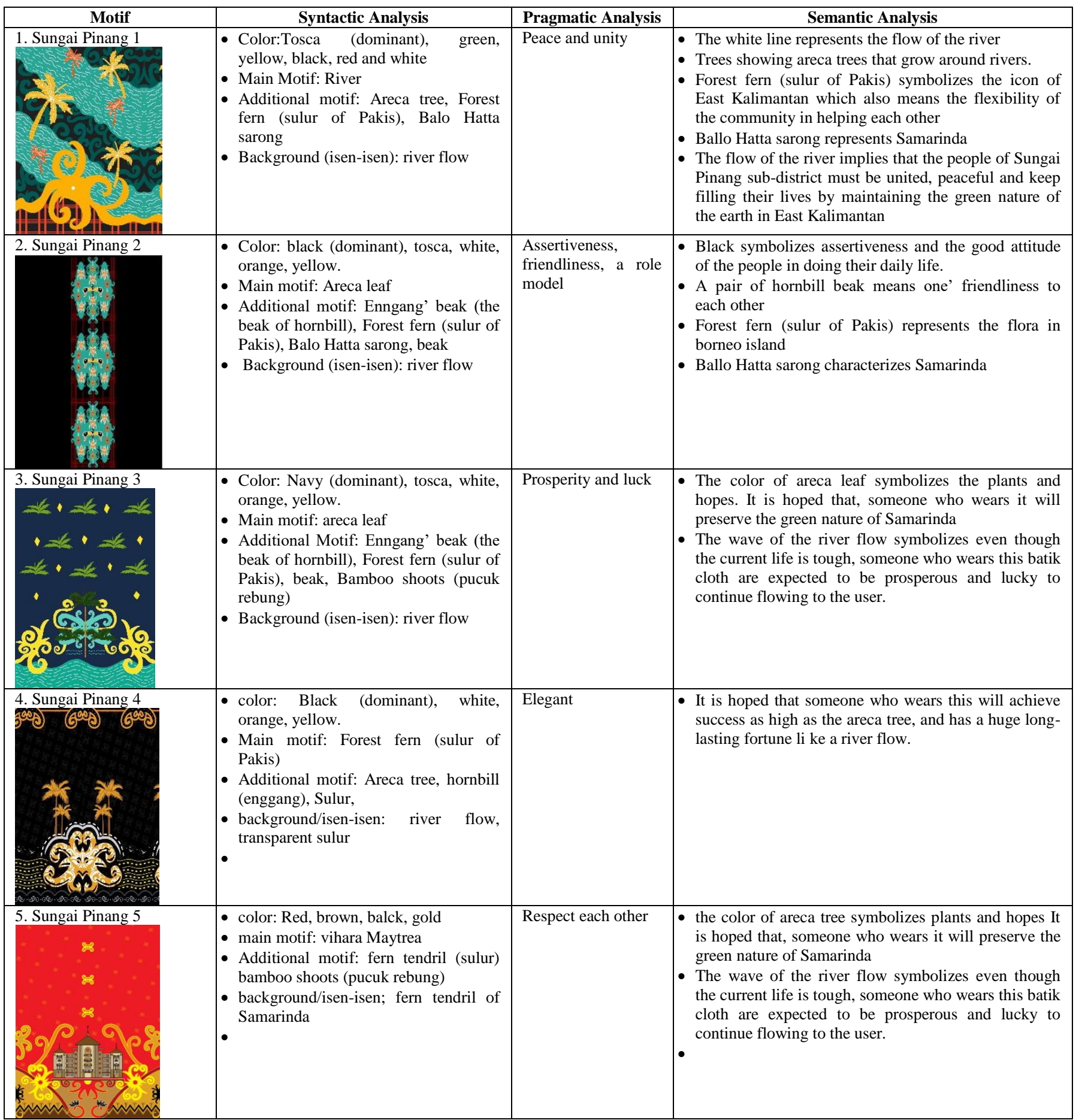

In designing a piece of batik fabric has complex meanings, ranging from the meaning of explicit, i.e. meaning based on what (denotative), as well as the meaning of deeper, relating to the with ideological understandings connotative [28]. Table 3 describes the meaning implied in 5 batik designs of Sungai Pinang sub-district designed based on semantic analysis. 


\section{CONCLUSION}

The signs in Batik sub-district of Sungai Pinang are a number of signs containing relationship elements as a story concept that describes the character, natural resources, culture and tourism of area in the sub-district of Sungai Pinang.

Based on the above discussion, it was produced 5 batik designs that fit the concept of semantics. From the results of these five designs are expected to be characteristic of the region and can be promotional materials as well as souvenirs in the tourism sector.

\section{ACKNOWLEDGMENT}

For enthusiastically participating and supporting our study, we would like to heartily thank Politeknik Negeri Samarinda, Pokant Takaq, Atiiqna Batics, and Iwak Batics for their efforts and contributions in assisting us in this study.

\section{REFERENCES}

[1] M. Srikandini, J.K. Runtuk, and L.P.S. Hartanti, "Rekayasa Desain Batik Tulis Jetis-Sidoarjo Melalui Implementasi Metode Kansei Engineering," Jurnal GEMA AKTUALITA, vol. 1 no. 1, 2012.

[2] A. Syarief and Y. Sunarya, "The Semantics of "New" Batik Clothes: Identifying Users'Perception on the Colors and Patterns of Newly Developed West Javanese Batik Clothes," ITB J. Vis. Art. vol. 1 D, no. 3, pp. 319-329, 2007.

[3] H.A. Sudabyo, "Pengembangan Motif Batik Bondowoso Sebaga Ekspresi Akulturasi Budaya," ABDIMAS: Jurnal Pengabdian Masyarakat Universitas Merdeka Malang, vol. 1, no. 1, 2016

[4] S.E. Nurhidayati, "Batik Tanjung bumi as Supporting of Tourism Industry in Madurese Island," PAHMI nineth International Conference, September, 2015.

[5] A. Kusrianto, Batik Filosofi, Motif \&Kegunan. Yogyakarta: Andi, 2014. p. 320.

[6] Zulfah, "Ragam Hias Batik Madura, Rumah Batik (Bangkalan)," p. 60, 2010

[7] M. Purbasari, "Batik Gringsing Bantulan dalam Perspektif Bentuk Motif Warna dan Makna Simbolik Relevansinya dengan Fungsi," Jurnal Pend. Seni Kerajinan - S1 (e-Craft), vol. 2, no. 4, 2013.

[8] G. Yule, The study of language-fourth edition. Cambridge: Cambridge University Press, 2010.

[9] J.R. Hurford, B. Heasley, and M.B. Smith, Semantics a coursebook. Cambridge: Cambridge University Press, 2010.

[10] S.W. Mayr, "Reading culture in TV commercials: A semiotic analysis of a TV commercial for the purpose of teaching culture to foreign language students," International Journal of Arts and Commerce, vol. 2, no. 1, pp. 86-100, 2013

[11] O. Demirbilek and B. Sener, "Product Design, Semantics, and emotional Response," Ergonomics, vol. 46, no. 13/14, pp. 1346-1360, 2003

[12] H. Riley, "Where do meanings come from? The social semiotic of design," The 2nd European Academy of Design Conference, 2001.

[13] H. Sunde, "How design can affect user response and behavior," [online] Retrieved from https://www.semanticscholar.org/paper

[14] B. Mudjiyanto and E. Nur, "Semiotika Dalam Metode Penelitian Komunikasi. Jurnal Penelitian Komunikasi," Informatika dan Media Massa t PEKOMMAS, pp. 73-82, 2013.

[15] T. Putri, "Kenali 5 Motif Batik dari Kalimantan Timur, Ibu Kota Baru Indonesia," Jurnalis, 2020

[16] Sumartono, "Semantik dan netnografi sebagai pendekatan penelitian untuk perancangan kembali (redesign) sebuah produk," Productum: Jurnal Desain Produk (Pengetahuan dan Perancangan Produk), vol. 3 , no. 3, pp. 95-100, 2018.

[17] C.F. Tsai, "A Review of Image Retrieval Methods for Digital Cultura Heritage Resources,” Online Information Review, vo. 312, pp. 185-198, 2007.

[18] R. Setchi and C. Bouchard, "In search of design inspiration : A Semantic - Based Approavh," Journal of Computing and Information Science in Engineering, 2010.

[19] F.Y. Tyas, "Analisis Semiotika Motif Batik Khas Samarinda," eJournal Ilmu Komunikasi, vol. 1, no. 4, pp. 328-339, 2013.

[20] A. Wulandari, Batik Nusantara, makna simbolik (cara pembuatan, dan industri batik). Yogyakarta: CV. Andi Offset, 2011.

[21] Dewan Kerajinan Nasional Daerah Propinsi Kalimantan Timur, Buku Motif Khas Dayak Kalimantan Timjur, Kalimantan Timur: Dekranasda, 2012.

[22] J. Creswell, Research Design: Qualitative, Quantitative, and Mixed Methods Approaches. 4th Edition. Sage Publications, 2014

[23] C. Bouchard, "Modelization of the Car Design Process," Ph.D. thesis, ENSAM, Paris, France, 1997.

[24] Sumartono, "Semantik dan netnografi sebagai pendekatan penelitian untuk perancangan kembali (redesign) sebuah produk," Productum: Jurnal Desain Produk (Pengetahuan dan Perancangan Produk), vol. 3 , no. 3, pp. 95-100, 2018

[25] P.I. Ansburg and K. Hill, "Creative and Analytic Thinkers Differ in Their Use of Attentional Resources," PAID, vol. 34, 2003.

[26] C. Eckert and M.K. Stacey, "Sources of Inspiration: A Language of Design,” Des. Stud., vol. 21, pp. 99-112, 2000.

[27] Y. Huang, C.H. Chen, and L.P. Khoo, "Product Classificationin in Emotional Design using a Basic - Emotion Based Semantics Differential Method," International Journal of Industrial Ergonomic, vol. 42, pp. 569-580, 2012.

[28] S. Pramono, S. Sabana, A. Haldani, and A.I. Saidi, "Semiotika Visua Dalam Pertukaran Tanda Dan Makna Sosial Politik Pada Batik Karya Hardjonagoro Go Tik Swan,” Jurnal Sosioteknologi, vol. 18, no. 3, pp. 497-508, 2019 